\title{
Outcome of pregnancy in women with cystic fibrosis
}

\author{
F P Edenborough, D E Stableforth, A K Webb, W E Mackenzie, D L Smith
}

\begin{abstract}
Background - As women with cystic fibrosis are living longer, pregnancy is becoming increasingly common. The combined experience of pregnancies in women with cystic fibrosis from adult centres in the Midlands and North of England has been examined.

Methods - A retrospective study of the case notes of 22 pregnancies in 20 patients with cystic fibrosis examined changes in lung function, body weight, and microbiological status during the course of pregnancy. Duration of pregnancy, birth weight, and maternal survival were amongst other variables studied. The relation between values before pregnancy and important outcome measures were examined.
\end{abstract}

Results - Eighteen of 22 pregnancies were completed producing healthy, non-cystic fibrosis infants (12 female). Mothers lost $13 \%$ of $\mathrm{FEV}_{1}$ and $11 \%$ of FVC during pregnancy, most of which was regained. Body weight changes were variable, but most mothers gained weight (mean weight gain $5 \cdot 7 \mathrm{~kg}$ ). Microbiological status remained unchanged. Six infants were preterm and two were light for dates. Four mothers died up to $3 \cdot 2$ years following delivery. Of the prepregnancy parameters examined, $\%$ \%EV $_{1}$ showed the best correlation with maternal weight gain, gestation, birth weight, and maternal survival.

Conclusions - Pregnancy was well tolerated by most mothers with cystic fibrosis although those with moderate to severe lung disease $\left(\% \mathrm{FEV}_{1}<60 \%\right)$ before pregnancy fared worse, producing preterm infants and suffering increased loss of lung function and mortality compared with mildly affected mothers. Prepregnancy $\% \mathrm{FEV}_{1}$ appears to be the most useful predictor of important outcome measures in pregnancies in women with cystic fibrosis. (Thorax 1995;50:170-174)

Keywords: cystic fibrosis, outcome, pregnancy.

Patients with cystic fibrosis are living longer. ${ }^{1}$ As the numbers surviving to adulthood increase, pregnancy in young women with cystic fibrosis, previously a rare event, is now becoming increasingly common. The first report of a successful pregnancy in a patient with cystic fibrosis appeared in $1960^{2}$; by 1976 a cumulative total of 129 pregnancies in 100 women was identified in the USA and Canada ${ }^{3}$ and in 1990 alone the Cystic Fibrosis Foundation in the USA was notified of 111 pregnancies occurring in the national network of cystic fibrosis care centres. ${ }^{4}$ Increasing numbers of pregnancies have also been noted in Europe. ${ }^{5}$

Those involved in caring for adults with cystic fibrosis are encountering increasing numbers of patients seeking guidance about the advisability of pregnancy. What counselling should they offer? A recent review article ${ }^{6}$ commented that prepregnancy lung function and body weight might be useful indicators of outcome for both mother and child. We have combined the experience of our own and neighbouring cystic fibrosis centres in the UK to provide guidelines for the clinical care and counselling of these patients.

\section{Methods}

The case notes of 22 pregnancies in 20 women with cystic fibrosis attending specialist centres in the Midlands and North of England were reviewed. These centres provide full or shared care for about 400 adults with cystic fibrosis, just less than half of whom are women. The data were taken from detailed records available between 1982 and 1992. Accurate record keeping in these specialist centres allowed the collection of the results of serial lung function tests, body weight, and repeated sputum cultures spanning all the pregnancies studied.

Lung function data (presented as either absolute values of forced expiratory volume in one second $\left(\mathrm{FEV}_{1}\right)$ and forced vital capacity (FVC) measured in litres or as percentage predicted values $\left.\left(\% \mathrm{FEV}_{1}, \% \mathrm{FVC}\right)\right)^{7}$ for each pregnancy were collected over three periods of time. Prepregnancy figures were the best recorded for each individual in the three months before pregnancy. Lung function at the end of pregnancy reflects the last recorded set of measurements for each individual before delivery. For the assessment of lung function after pregnancy the best figures achieved in the year following pregnancy were chosen, as lung function continued to improve in some mothers for up to one year after pregnancy. Changes in body weight (presented as either absolute values in kilograms or percentage predicted ideal body weight $(\% \mathrm{IBW})^{8}$ were taken from measurements made over the same periods of time. Sputum cultures taken over the last year prior to, during, and for the year following pregnancy were examined to determine changes (if any) in the flora of each individual's respiratory tract which might influence the subsequent rate of progression of pulmonary disease. Data were also collected on diabetic status, smoking history, and pancreatic sufficiency at the beginning of each pregnancy. 
Table 1 Details of prepregnancy parameters and outcome of 22 pregnancies in 20 women with cystic fibrosis ranked by percentage predicted forced expiratory volume in one second $(F E V)$

\begin{tabular}{|c|c|c|c|c|c|c|c|c|c|c|c|c|}
\hline $\begin{array}{l}\text { Age } \\
\text { (yrs) }\end{array}$ & $\begin{array}{l}F E V_{1} \\
\text { (litres) } \\
\text { [\%pred] }\end{array}$ & $\begin{array}{l}\text { FVC } \\
\text { (litres) } \\
\text { [\%pred] }\end{array}$ & $\begin{array}{l}\text { Weight } \\
(\mathrm{kg}) \\
{[\% \text { pred] }}\end{array}$ & Microbiology & $\begin{array}{l}\text { Insulin } \\
\text { dependent } \\
\text { diabetic }\end{array}$ & $\begin{array}{l}\text { Current/ex- } \\
\text { smoker }\end{array}$ & $\begin{array}{l}\text { Gestation } \\
\text { (weeks) }\end{array}$ & $\begin{array}{l}\text { Mode of } \\
\text { delivery }\end{array}$ & $\begin{array}{l}\text { Birth } \\
\text { weight } \\
\text { (kg) }\end{array}$ & $\begin{array}{l}\text { Age of } \\
\text { child } \\
\text { (years) }\end{array}$ & $\begin{array}{l}\text { Maternal } \\
\text { outcome } \\
\text { [duration } \\
\text { postpartum in } \\
\text { years] }\end{array}$ & Comments \\
\hline $\begin{array}{l}18 \\
15 \\
23 \\
20 \\
20\end{array}$ & $\begin{array}{l}3 \cdot 4[101] \\
2 \cdot 9[98] \\
2 \cdot 7[91] \\
2 \cdot 8[90] \\
2 \cdot 9[89]\end{array}$ & $\begin{array}{l}3 \cdot 9[102] \\
3 \cdot 3[97] \\
3 \cdot 3[99] \\
3 \cdot 5[100] \\
3 \cdot 4[89]\end{array}$ & $\begin{array}{l}57 \cdot 1[105] \\
54 \cdot 7[101] \\
49 \cdot 2[98] \\
49 \cdot 0[92] \\
54 \cdot 5[100]\end{array}$ & $\begin{array}{l}\text { Ps aeruginosa } \\
\text { Staph aureus } \\
\text { Normal flora } \\
\text { Ps aeruginosa } \\
\text { Ps aeruginosa }\end{array}$ & $\begin{array}{l}\text { No } \\
\text { No } \\
\text { No } \\
\text { No } \\
\text { No }\end{array}$ & $\begin{array}{l}\text { No } \\
\text { Yes } \\
\text { Yes } \\
\text { No } \\
\text { Yes }\end{array}$ & $\begin{array}{l}38 \\
40 \\
40 \\
40 \\
10\end{array}$ & $\begin{array}{l}\text { NVD } \\
\text { NVD } \\
\text { Forceps } \\
\text { NVD } \\
-\end{array}$ & $\begin{array}{l}3 \cdot 5 \\
4 \cdot 1 \\
3 \cdot 4 \\
2 \cdot 9 \\
-\end{array}$ & $\begin{array}{l}3 \\
4 \cdot 5 \\
7 \cdot 25 \\
12 \cdot 2 \\
-\end{array}$ & $\begin{array}{l}\text { Alive } \\
\text { Alive } \\
\text { Alive } \\
\text { Alive } \\
\text { Alive }\end{array}$ & ineous \\
\hline $\begin{array}{l}21 \\
27 \\
21 \\
26 \\
19 \\
25 \\
20\end{array}$ & $\begin{array}{l}3 \cdot 0[86] \\
2 \cdot 5[84] \\
2 \cdot 5[78] \\
2 \cdot 5[77] \\
2 \cdot 1[71] \\
2 \cdot 4[69] \\
2 \cdot 3[68]\end{array}$ & $\begin{array}{l}4 \cdot 1[102] \\
3 \cdot 3[91] \\
3 \cdot 3[90] \\
3 \cdot 5[96] \\
2 \cdot 4[71] \\
3 \cdot 5[88] \\
3 \cdot 4[87]\end{array}$ & $\begin{array}{l}52 \cdot 6[91] \\
49 \cdot 0[91] \\
48 \cdot 5[92] \\
47 \cdot 1[86] \\
49 \cdot 0[98] \\
57 \cdot 5[100] \\
47 \cdot 5[86]\end{array}$ & $\begin{array}{l}\text { Staph aureus } \\
\text { Staph aureus } \\
\text { Ps aeruginosa } \\
\text { Ps aeruginosa } \\
\text { Ps aeruginosa } \\
\text { Ps aeruginosa } \\
\text { Ps cepacia }\end{array}$ & $\begin{array}{l}\text { No } \\
\text { Yes } \\
\text { No } \\
\text { No } \\
\text { No } \\
\text { No } \\
\text { Yes }\end{array}$ & $\begin{array}{l}\text { No } \\
\text { No } \\
\text { Yes } \\
\text { Yes } \\
\text { No } \\
\text { No } \\
\text { Yes }\end{array}$ & $\begin{array}{l}40 \\
38 \\
39 \\
40 \\
37 \\
38 \\
18\end{array}$ & $\begin{array}{l}\text { NVD } \\
\text { Caesarean } \\
\text { NVD } \\
\text { Forceps } \\
\text { Forceps } \\
\text { NVD } \\
-\end{array}$ & $\begin{array}{l}3 \cdot 1 \\
3 \cdot 6 \\
2 \cdot 8 \\
4 \cdot 0 \\
2 \cdot 9 \\
3 \cdot 1 \\
-\end{array}$ & $\begin{array}{l}5 \cdot 6 \\
8 \cdot 5 \\
8 \cdot 4 \\
1 \cdot 8 \\
4 \cdot 9 \\
1 \\
-\end{array}$ & $\begin{array}{l}\text { Alive } \\
\text { Alive } \\
\text { Alive } \\
\text { Alive } \\
\text { Alive } \\
\text { Alive } \\
\text { Alive }\end{array}$ & $\begin{array}{l}\text { Therapeutic } \\
\text { abortion, fetal } \\
\text { anomalies }\end{array}$ \\
\hline $\begin{array}{l}19 \\
17 \\
17 \\
16 \\
27\end{array}$ & $\begin{array}{l}2.0[66] \\
2.0[66] \\
1.6[61] \\
1.4[51] \\
1.5[50]\end{array}$ & $\begin{array}{l}3 \cdot 2[90] \\
2 \cdot 6[75] \\
2 \cdot 0[74] \\
1 \cdot 8[57] \\
2 \cdot 3[70]\end{array}$ & $\begin{array}{l}46 \cdot 5[89] \\
42 \cdot 8[84] \\
48 \cdot 2[89] \\
39 \cdot 0[81] \\
44 \cdot 0[85]\end{array}$ & $\begin{array}{l}\text { Ps aeruginosa } \\
\text { Ps aeruginosa } \\
\text { Ps aeruginosa } \\
\text { Ps aeruginosa } \\
\text { Ps aeruginosa }\end{array}$ & $\begin{array}{l}\text { No } \\
\text { No } \\
\text { No } \\
\text { No } \\
\text { No }\end{array}$ & $\begin{array}{l}\text { Yes } \\
\text { Yes } \\
\text { No } \\
? \\
\text { No }\end{array}$ & $\begin{array}{l}31 \\
10 \\
37 \\
34 \\
37\end{array}$ & $\begin{array}{l}\text { Caesarean } \\
- \\
\text { NVD } \\
\text { Caesarean } \\
\text { Caesarean }\end{array}$ & $\begin{array}{l}1 \cdot 5 \\
- \\
3 \cdot 0 \\
2 \cdot 4 \\
2 \cdot 4\end{array}$ & $\begin{array}{l}1 \cdot 1 \\
- \\
11 \cdot 3 \\
2 \cdot 1 \\
4 \cdot 75\end{array}$ & $\begin{array}{l}\text { Alive } \\
\text { Deceased [2.4] } \\
\text { Alive } \\
\text { Alive } \\
\text { Deceased [3.2] }\end{array}$ & $\begin{array}{l}\text { Rib fracture during } \\
\text { pregnancy, pre- } \\
\text { eclampsia }\end{array}$ \\
\hline $\begin{array}{l}23 \\
25 \\
25\end{array}$ & $\begin{array}{l}1.5[50] \\
1.6[49] \\
1.2[39]\end{array}$ & $\begin{array}{l}2 \cdot 0[61] \\
2 \cdot 0[53] \\
2 \cdot 5[71]\end{array}$ & $\begin{array}{l}41 \cdot 0[82] \\
52 \cdot 9[96] \\
45 \cdot 0[83]\end{array}$ & $\begin{array}{l}\text { Staph aureus } \\
\text { Ps aeruginosa } \\
\text { Ps aeruginosa }\end{array}$ & $\begin{array}{l}\text { No } \\
\text { No } \\
\text { No }\end{array}$ & $\begin{array}{l}? \\
\text { Yes } \\
\text { No }\end{array}$ & $\begin{array}{l}33 \\
36 \\
34\end{array}$ & $\begin{array}{l}\text { Forceps } \\
\text { Ventouse } \\
\text { Caesarean }\end{array}$ & $\begin{array}{l}2 \cdot 4 \\
2 \cdot 5 \\
1 \cdot 9\end{array}$ & $\begin{array}{l}9 \cdot 4 \\
2 \cdot 6 \\
4 \cdot 75\end{array}$ & $\begin{array}{l}\text { Deceased }[2 \cdot 4] \\
\text { Deceased }[0.5] \\
\text { Deceased }[1 \cdot 8]\end{array}$ & $\begin{array}{l}\text { Third trimester } \\
\text { pneumothorax, } \\
\text { infant in incubator } \\
\text { overnight }\end{array}$ \\
\hline $\begin{array}{l}21 \\
25\end{array}$ & $\begin{array}{l}1 \cdot 0[32] \\
1 \cdot 0[28]\end{array}$ & $\begin{array}{l}1.5[42] \\
1.5[38]\end{array}$ & $\begin{array}{l}44 \cdot 5[82] \\
58 \cdot 0[97]\end{array}$ & $\begin{array}{l}\text { Ps aeruginosa } \\
\text { Ps aeruginosa }\end{array}$ & $\begin{array}{l}\text { No } \\
\text { Yes }\end{array}$ & $\begin{array}{l}\text { No } \\
\text { No }\end{array}$ & $\begin{array}{l}7 \\
32\end{array}$ & $\overline{\text { Caesarean }}$ & $\overline{1.5}$ & $\overline{0} \cdot 9$ & $\begin{array}{l}\text { Alive } \\
\text { Alive }\end{array}$ & $\begin{array}{l}\text { Therapeutic abortion } \\
\text { Infant ventilated }\end{array}$ \\
\hline
\end{tabular}

$?=$ Data unavailable; $\mathrm{NVD}=$ normal vaginal delivery.

Details of the planning and duration of pregnancy, onset and mode of delivery, birth weight, Apgar scores, and sex of the infant and complications occurring during pregnancy and delivery were collected from both medical case notes and obstetric records.

In order to assist in the development of guidelines for patients with cystic fibrosis considering pregnancy, the relations between prepregnancy maternal parameters and outcome measures (weight changes during and after pregnancy, changes in lung function during and after pregnancy, duration of pregnancy, methods of delivery, birth weight, and maternal survival) were explored with the aid of appropriate correlation matrices.

\section{Results}

Prepregnancy data for all 20 patients and 22 pregnancies are shown in table 1 (two patients who had two pregnancies are listed twice, each set of data relating to an individual pregnancy). The patients had a mean age of 21 (range 15-27) years at the onset of pregnancy. Pregnancy had been planned in 11 cases. Prepregnancy lung function showed mean values of $\mathrm{FEV}_{1}$ of $2 \cdot 1$ (range $\left.1 \cdot 0-3 \cdot 4\right)$ litres $\left(\% \mathrm{FEV}_{\text {, }}\right.$ $68 \%)$ and FVC of $2 \cdot 8(1 \cdot 5-4 \cdot 1)$ litres (\%FVC $79 \%)$. Mean body weight for the group was 48.9 (39-58) kg (\%IBW 91\%). All patients had pancreatic insufficiency, 16 were chronically colonised with Pseudomonas aeruginosa and one with Pseudomonas cepacia. There were three insulin dependent diabetics and nine were current or ex-smokers at the onset of pregnancy. No antenatal diagnostic procedures for cystic fibrosis were performed on any fetus although none were available at the time of pregnancy for some mothers. Paternal genetic screening was accepted by all couples to whom it was offered. Laparascopic sterilisation was performed for four mothers following their pregnancies.

\section{INCOMPLETE PREGNANCIES}

Four of the pregnancies were incomplete. Two patients underwent therapeutic abortions at seven and 10 weeks for psychosocial reasons, although one of these subsequently had a successful second pregnancy. A third patient underwent abortion at 18 weeks due to the discovery of fetal anomalies (diaphragmatic hernia and pulmonary hypoplasia) on routine antenatal ultrasound examination. This patient had received $63 \mathrm{~g}$ ciprofloxacin and $100 \mathrm{~g}$ flucloxacillin orally, with $170 \mathrm{~g}$ azlocillin and $3.7 \mathrm{~g}$ gentamicin intravenously during the first trimester of pregnancy. A literature search (Medline) failed to show any reported association between these drugs and the anomalies found which have a naturally occurring frequency of 1:2000 births in a normal population. ${ }^{9}$ The fourth patient spontaneously aborted in the tenth week of pregnancy.

\section{COMPLETED PREGNANCIES}

The remaining 18 pregnancies in 17 patients produced healthy, non-cystic fibrosis children of whom $12(66 \%)$ were female. The mean (SD) duration of pregnancy was $37(2 \cdot 9)$ weeks (range 31-40) with six infants being preterm (gestation <37 weeks). Seven mothers had unassisted vaginal deliveries, four required forceps, and one ventouse assistance. The remaining six mothers required caesarean sections, all performed preterm because of deteriorating maternal pulmonary function. Birth 


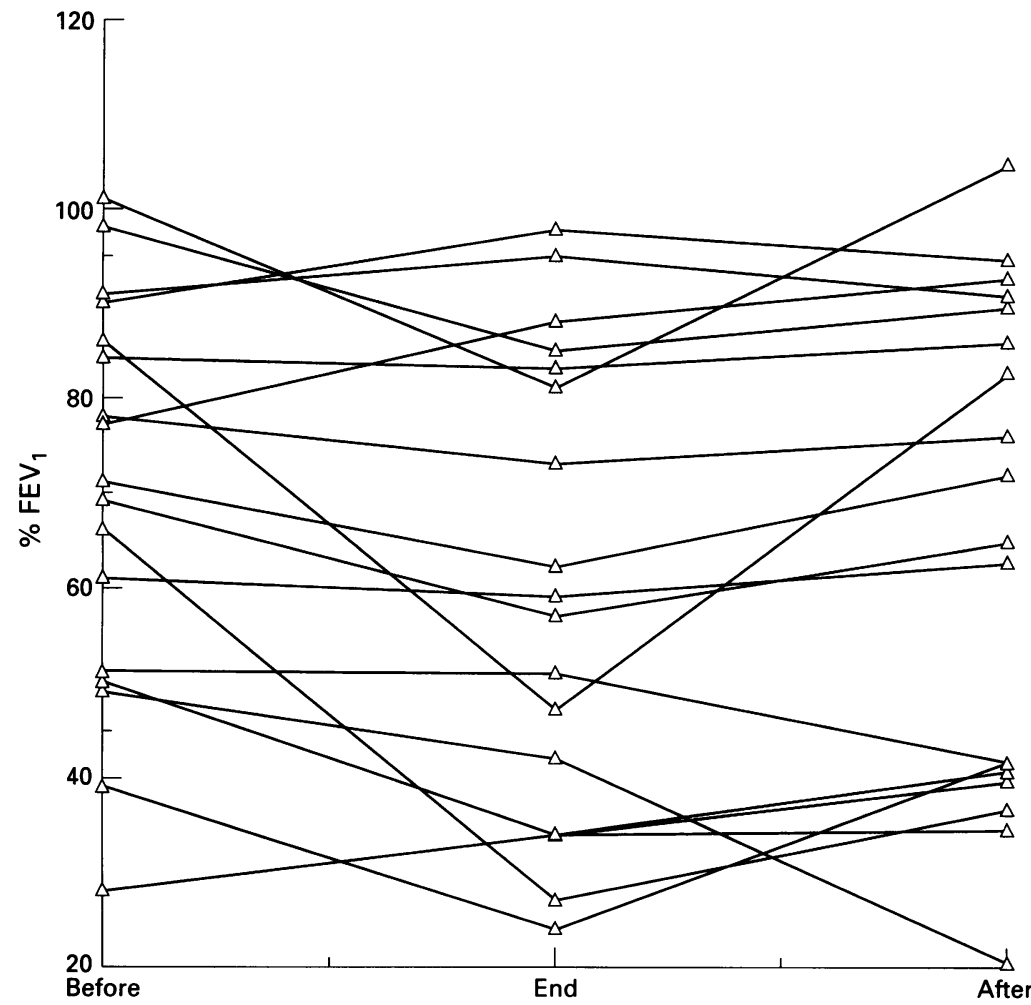

Figure 1 Changes in maternal percentage predicted forced expiratory volume in one second (\%FEV $)$ during and after 18 pregnancies in 17 women with cystic fibrosis.

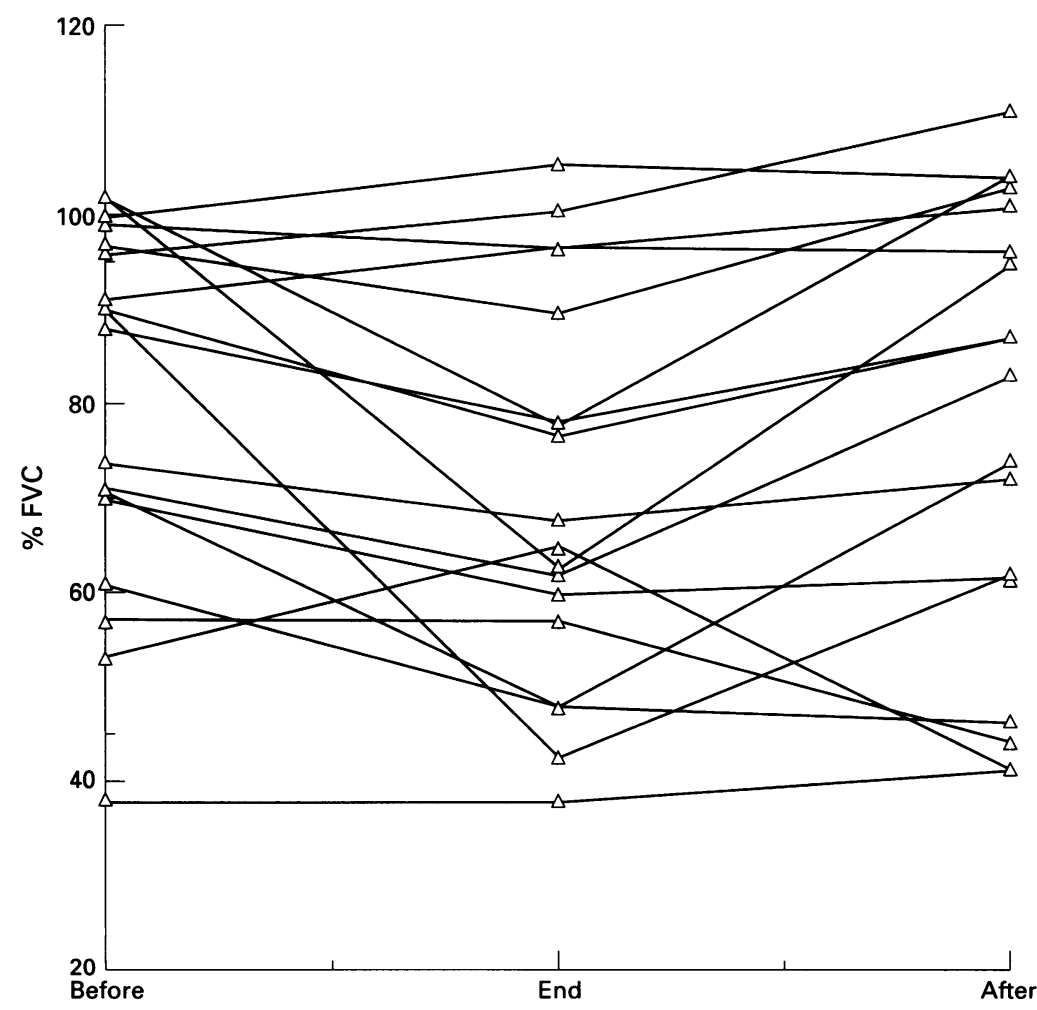

Figure 2 Changes in maternal percentage predicted forced vital capacity (\%FVC) during and after 18 pregnancies in 17 women with cystic fibrosis.

weights ranged from $1 \cdot 5 \mathrm{~kg}$ to $4 \cdot 1(0 \cdot 7) \mathrm{kg}$ with a mean value of $2.9 \mathrm{~kg}$. Two infants were light for dates, being below the $10 \%$ percentile for gestational age at birth. Apgar scores at one and five minutes were available for 13 of the pregnancies with mean values of 8 at one minute and 10 at five minutes. The lowest Apgar score was 5 at one minute (to a mother with moderate to severe prepregnancy lung disease, $\% \mathrm{FEV}_{1} 49 \%$ ) in one infant who improved to a score of 10 at five minutes. Two babies required a degree of intensive support in the neonatal period; one infant spent 12 hours in an incubator whilst the second required assisted ventilation. Both survived and subsequently did well. None of the babies had congenital anomalies.

EFFECT OF PREGNANCY ON MATERNAL

PARAMETERS

Changes in lung function during and after pregnancy for all patients are shown in figs 1 and 2. The general pattern seen was that of a loss in lung function during pregnancy which was largely regained following pregnancy. The group as a whole lost $13 \%$ of $\mathrm{FEV}_{1}$ and $11 \%$ of FVC during pregnancy; one year after pregnancy the loss in $\mathrm{FEV}_{1}$ was only $5 \%$ and in FVC was $2 \%$. Individual patterns were quite variable, however, and some patients gained lung function during pregnancy whilst others suffered an increased rate of loss of lung function after pregnancy compared with that seen during pregnancy. Changes in body weight during and after pregnancy are shown in fig 3. The pattern for the group as a whole was one of a weight gain of $11 \%$ (an absolute gain of $5.7 \mathrm{~kg}$ ) during pregnancy which was subsequently lost after pregnancy with no overall weight change one year after delivery. Again, individual patterns were quite variable; two patients lost weight during pregnancy and seven had lost weight up to one year after pregnancy compared with prepregnancy values.

Microbiological status remained unchanged for all mothers during pregnancy. No patients acquired either intermittent (single culture) or chronic (more than three cultures in six months) Pseudomonas colonisation over the period of assessment.

Significant complications arising during pregnancy included a third trimester tension pneumothorax in one patient and a rib fracture and pre-eclampsia in a second, both of whom had moderate to severe prepregnancy pulmonary disease $\left(\% \mathrm{FEV}_{1} 39 \%\right.$ and $\left.50 \%\right)$ and have subsequently died.

Overall there have been four maternal deaths amongst the 17 patients who had successful pregnancies, all in mothers with moderate to severe lung disease at the onset of pregnancy ( $\% \mathrm{FEV}_{1}$ values of $39 \%, 49 \%, 50 \%$, and $50 \%$ ). These deaths occurred at $0 \cdot 5,1 \cdot 8,2 \cdot 4$, and $3 \cdot 2$ years after delivery. All of these mothers lost more than $10 \%$ of $\mathrm{FEV}_{1}$ during pregnancy which three of them failed to regain up to one year (six months in the case of one patient) after delivery. All the mothers with mild lung disease $\left(\% \mathrm{FEV}_{1}>60 \%\right)$ and two with severe lung disease $\left(\% \mathrm{FEV}_{1} 28 \%\right.$ and $\left.32 \%\right)$ at the onset of pregnancy survive with children ranging from 0.9 to 12 years of age, although one of these mothers who lost $56 \%$ of her $\mathrm{FEV}_{1}$ during pregnancy was listed for heart-lung transplantation three months after delivery. 


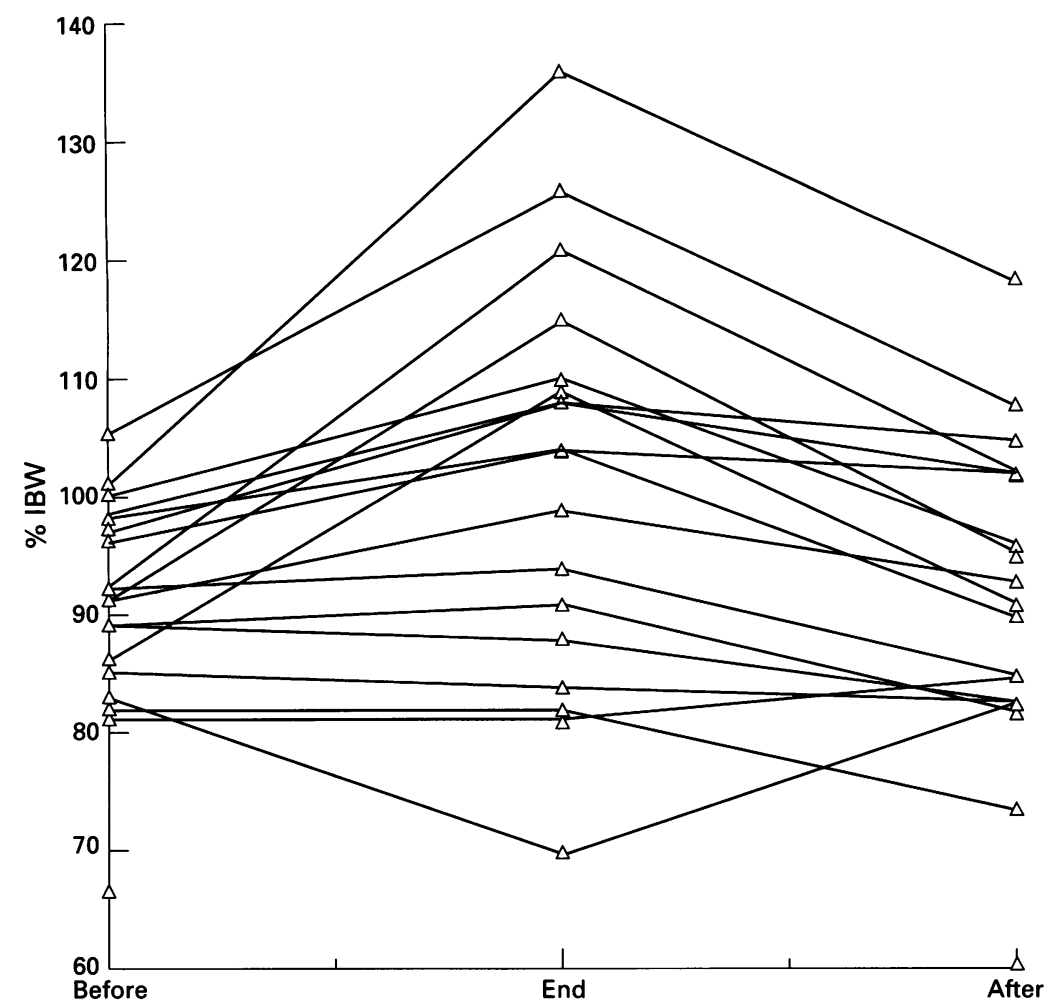

Figure 3 Changes in maternal percentage predicted ideal body weight (\%IBW) during and after 18 pregnancies in 17 women with cystic fibrosis.

\section{OUTCOME PREDICTORS}

Since all data were normally distributed, Pearson's partial correlation coefficients were used to examine the relations between parameters before pregnancy and outcome measures. These values are shown in table 2 . Weight gain during pregnancy was positively correlated with prepregnancy $\% \mathrm{FEV}_{1}$ but not with $\% \mathrm{FVC}$ or \%IBW. Changes in body weight after pregnancy and changes in lung function during and after pregnancy were not correlated with any prepregnancy parameters. Duration of pregnancy was positively correlated with lung function before pregnancy (both $\% \mathrm{FEV}_{1}$ and $\%$ FVC) but not with \%IBW, those mothers with better lung function carrying their pregnancies closer to term. Birth weight was positively correlated with prepregnancy lung function (both $\% \mathrm{FEV}_{1}$ and $\% \mathrm{FVC}$ ) but not \%IBW; again those mothers with better lung function produced heavier offspring, probably as a consequence of their longer gestation. Maternal survival was positively correlated with prepregnancy $\% \mathrm{FEV}_{1}$. Caesarean section was

Table 2 Correlation between prepregnancy parameters and important outcome measures in 18 pregnancies occurring in 17 women with cystic fibrosis

\begin{tabular}{llll}
\hline Prepregnancy parameter & Outcome measure & $\begin{array}{l}\text { Correlation } \\
\text { coefficient }\end{array}$ & $p$ \\
\hline \%FEV $_{1}$ & Weight gain during pregnancy 0.63 & $<0.01$ \\
& Duration of pregnancy & 0.77 & $<0.001$ \\
& Birth weight & 0.78 & $<0.001$ \\
\%FVC & Maternal survival & 0.56 & $<0.02$ \\
& Duration of pregnancy & 0.77 & $<0.001$ \\
\%IBW & Birth weight & 0.65 & $<0.01$ \\
& Caesarean section & -0.57 & $<0.02$ \\
\hline
\end{tabular}

$\mathrm{FEV}_{1}=$ forced expiratory volume in one second; $\mathrm{FVC}=$ forced vital capacity; IBW = ideal body weight.

* Pearson's partial correlation coefficient. negatively correlated with prepregnancy \%IBW, underweight mothers being more likely to require caesarean sections. It would appear that, for most outcome measures, it is the value of $\% \mathrm{FEV}_{1}$ before pregnancy that has most influence.

\section{Discussion}

The literature suggests that early experience with pregnancy in cystic fibrosis was fraught with difficulties and often led to a poor outcome for both mother and child. Grand in $1966^{10}$ reported on 13 pregnancies in 10 patients with cystic fibrosis, commenting that in half the patients pregnancy led to a serious deterioration in pulmonary function and two died within five weeks of delivery. Three of the 13 pregnancies produced premature infants and two infants died, one stillborn and one in the immediate perinatal period. Recent publications have reported a better outcome, particularly in mothers with mild disease. ${ }^{11} \mathrm{~A}$ recent comprehensive review ${ }^{12}$ concluded that "pregnancy is well tolerated by patients with mild disease whilst associated with increased maternal and fetal complications in those with severe disease".

The experience of our own and neighbouring cystic fibrosis centres in the UK is broadly in keeping with that reported from Canada ${ }^{13}$ in a recent comparable series of 38 pregnancies in 25 patients with cystic fibrosis between 1963 and 1990. Overall these pregnancies were well tolerated with little demonstrable effect on maternal pulmonary and nutritional status. Although these patients were older than those in our study (mean age 25 versus 21 years), they exhibited similar prepregnancy lung function $\left(\% \mathrm{FEV}_{1} 66\right.$ versus 68$)$ but did contain a large proportion (12 of 25) of patients with pancreatic sufficiency. This superior lung function for age compared with the UK group reflects the better outcome seen in patients with normal fat absorption ${ }^{14}$; the high proportion of pancreatic sufficient patients in the Canadian group probably represents selection on the basis of good clinical status. Four of the pregnancies were interrupted by abortion (in one case spontaneous), a similar rate to our own study. Maternal weight gain during pregnancy in the Canadian series was $10.4 \mathrm{~kg}$; our own patients achieved a lower weight gain of $5.4 \mathrm{~kg}$, probably because all had pancreatic insufficiency. One neonatal death occurred in the Canadian series, none in our own; two of the Canadian infants were preterm whereas six of those in our series were delivered before 37 weeks of gestation. No congenital anomalies in successful pregnancies were seen in either series. We saw no maternal deaths within six weeks of delivery, as was the case in the Canadian series. We have, however, seen four maternal deaths within 3.2 years of delivery; the Canadian series reported three maternal deaths occurring between 1.5 and 25 years of delivery. Overall, changes in lung function and body weight as a result of pregnancy were similar in both studies (loss of $\% \mathrm{FEV}_{1}$ Canada $6 \%$ versus UK $5 \%$, loss of weight Canada $1 \%$ versus UK no loss). 
Patients with cystic fibrosis frequently require antimicrobial therapy during pregnancy as was the case with most of our patients. Most clinicians try to avoid giving antimicrobial drugs during the first trimester and certain antibiotics such as tetracyclines and ciprofloxacin should be avoided throughout pregnancy. Aminoglycosides, often the mainstay of antipseudomonal chemotherapy in cystic fibrosis, are considered safe as long as serum levels are closely monitored ${ }^{12}$ and can be used by both intravenous and inhaled routes. Antipseudomonal penicillins and cephalosporins may also be used by both routes. Maintenance flucloxacillin, inhaled antibiotics, pancreatic enzymes (when appropriate), and vitamin supplements should be continued throughout pregnancy.

A high proportion of our patients (nine of $20,45 \%$ ) admitted to smoking at the time of becoming pregnant despite prior advice to the contrary. The effects of smoking on the unborn fetus may be used as an additional factor in attempting to persuade these patients to give up.

Antenatal screening for cystic fibrosis via chorionic villus sampling or amniocentesis may be appropriate if the partner of a mother with cystic fibrosis has been shown to carry a common cystic fibrosis mutation. This was not the case with any of our mothers whose partners were tested. The risk of an affected infant for a mother with cystic fibrosis whose partner does not carry a common cystic fibrosis gene (responsible for about $85 \%$ of the cystic fibrosis gene pool) is about 1:160; all offspring, however, will be obligate heterozygotes.

Various publications have suggested a number of prepregnancy parameters that might usefully be considered in assessing the likely outcome of a pregnancy in the individual with cystic fibrosis. Most have included some measure of lung function and nutritional status; others have also included radiographic features and clinical scoring systems. ${ }^{11}$ Our own study suggests that, of the parameters we have assessed, the $\% \mathrm{FEV}_{1}$ most influences important outcome measures of pregnancy in patients with cystic fibrosis. Mothers with a prepregnancy $\% \mathrm{FEV}_{1}$ of $>60 \%$ all did well, whilst two thirds of those with a prepregnancy $\% \mathrm{FEV}_{1}$ of $<60 \%$ died within 3.2 years of delivery. This mortality may in part reflect the natural progression of lung disease, although pregnancy itself caused a significant added decline since, in three of these four patients, the loss of $\% \mathrm{FEV}_{1}$ after pregnancy was much greater than for the group as a whole ( $37 \%$ versus $5 \%)$. Although most studies report only perinatal maternal mortality, the issue of maternal death within the preschool lifetime of the infant is clearly an important one. Similarly, mothers with moderate to severe prepregnancy pulmonary disease all had preterm infants (five of the six by caesarean section) compared with only one preterm infant (also by caesarian section) in the group of mothers with mild disease.

In summary, our experience is in keeping with that of others. ${ }^{12}$ No mothers or infants died in the immediate perinatal period in contrast to experiences in the 1960 s. Mothers with mild prepregnancy pulmonary disease tolerated pregnancy well. Those with moderate to severe disease are faced with an increased risk of pulmonary deterioration and the production of premature infants, although all infants of our mothers with moderate to severe disease have survived and remain healthy.

How should we advise our patients with cystic fibrosis who are considering pregnancy and motherhood? Clearly a number of issues need to be discussed. Even patients with excellent lung function may find that caring for a new baby considerably reduces the amount of time they have for their own treatment and physiotherapy. For those with more severe disease, their own health and the care of their baby may be compromised by progression of lung disease and the possibility that the mother may die before the child is very old also needs to be considered. Balanced against this is the generally good experience of mothers with good prepregnancy lung function. Quite where the emphasis should lie for each individual depends upon several factors, but our study underlines the usefulness of measurements of prepregnancy lung function in predicting the likely outcome for our patients.

We are grateful to Drs Green, Knox, McLellan, Page, and Weller for allowing us to study the case notes of patients under their care.

1 Elbourn JS, Shale DJ, Britton JR. Cystic fibrosis: current survival and population estimates to the year 2000 . Thorax 1991;46:881-5.

2 Siegel B, Siegel S. Pregnancy and delivery in a patient with CF of the pancreas. Obster Gynecol 1960;16:439-40.

3 Cohen LA, di Sant'Agnese PA, Freidlander J. Cystic fibrosis and pregnancy. A national survey. Lancet 1980;ii:842-4.

4 Kotloff RM, FitzSimmons SC, Fiel SB. Fertility and pregnancy in patients with cystic fibrosis. Clin Chest Med 1992; 13:623-35.

5 Metz OW, Metz S. Pregnancy and labor in mucovisidosis - results of a study in Germany. Klin Padiatr 1992;204: 145-9.

6 Geddes DM. Cystic fibrosis and pregnancy. $7 R$ Soc Med 1992;85(Suppl 9):36-7.

7 ECCS. Standardised lung function testing. Bull Eur Physiopathol Respir Clin Respir Physiol 1983;19(Suppl 5):1-95.

8 Jelliffe DB. The assessment of the nutritional status of the community. Geneva: World Health Organisation, Monograph Series No. 53, 1966.

9 Hanson T, Corbet A. Disorders of the chest wall and diaphragm. In: Taeusch HW, Ballard RA, Avery ME, eds. Schaffer's and Avery's diseases of the newborn. 6th edn. Philadelphia: Saunders, 1991:557-62.

10 Grand RJ, Talamo RC, di Sant'Agnese PA, Schwartz RH. Pregnancy in cystic fibrosis of the pancreas. $\mathscr{F} A M A 1966$; 195:117-24.

11 Corkey CWB, Newth CJL, Corey M, Levison H. Pregnancy in cystic fibrosis: a better prognosis in patients with pancreatic function? Am $\mathcal{f}$ Obstet Gynecol 1981;140:737-42.

12 Kotloff RM, FitzSimmons SC, Fiel SB. Fertility and pregnancy in patients with cystic fibrosis. Clin Chest Med 1992;
13:623-35.

13 Canney GJ, Corey M, Livingstone RA, Carpenter S, Green $\mathrm{L}$, Levison H. Pregnancy and cystic fibrosis. Obstet Gynecol L, Levison H. P

14 Gaskin K, Gurwitz D, Durie P, Corey M, Levinson H. Improved respiratory prognosis in patients with cystic fibrosis and normal fat absorption. $\mathcal{F}$ Pediatr 1982;100: 857-62. 